\title{
PENGARUH LIKUIDITAS, EFEKTIVITAS MODAL KERJA, LEVERAGE TERHADAP ROA DAN ROE PADA KPRI DI KABUPATEN LAMONGAN
}

\author{
Dwi Hari Prayitno \\ Fakultas Ekonomi, Universitas Islam Lamongan
}

\begin{abstract}
ABSTRAK
Tujuan Penelitian yaitu untuk mengetahui dan menganalisis tingkat Likuiditas, efektivitas modal kerja, leverage, ROA dan ROE pada KPRI di Kabupaten Lamongan serta untuk memperoleh data empiris ada tidaknya pengaruh likuiditas, efektivitas modal kerja, leverage terhadap ROA dan pengaruh likuiditas, efektivitas modal kerja, leverage terhadap ROE pada KPRI di Kabupaten Lamongan. Metode penelitian yang digunakan dalam penelitian ini adalah metode kuantitatif. Pemilihan sampel menggunakan teknik purposive sampling. Analisis data menggunakan analisis regresi linier berganda dan hipotesis diuji dengan $t$ test dan $F$ test dengan tingkat signifikan sebesar 5\%. Hasil Penelitian menunjukan bahwa variable likuiditas, efektivitas modal kerja, leverage secara bersama berpengaruh secara positif dan signifikan terhadap ROA dan variable likuiditas, efektivitas modal kerja, leverage secara bersama tidak berpengaruh secara positif dan signifikan terhadap ROE, namun secara individu variable likuiditas, efektivitas modal kerja berpengaruh secara negatef dan tidak signifikan terhadap ROA. variabel leverage berpengaruh secara negative dan signifikan terhadap ROA. Variable likuiditas, efektivitas modal kerja berpengaruh secara positif dan tidak signifikan terhadap ROE. Variabel leverage berpengaruh secara negatif dan signifikan terhadap ROE.
\end{abstract}

Kata kunci : likuiditas, efektivitas modal kerja, leverage, ROA, ROE

\section{PENDAHULUAN}

Koperasi merupakan kumpulan dari orang-orang yang berwatak sosial yang bekerja sama berdasarkan asas kekeluargaan dan gotong royong untuk memajukan kepentingan anggota dan masyarakat umum. Hal ini sesuai dengan tujuan utama koperasi yaitu meningkatkan kesejahteraan anggota dan masyarakat pada umumnya, agar dapat mencapai tujuan tersebut, koperasi berusaha memenuhi dan mencukupi kebutuhan anggotanya, dengan menyelenggarakan berbagai bidang usaha yang bermanfaat bagi masyarakat disekitarnya (Saraswati dkk, 2013). Keberhasilan koperasi dalam menjalankan usahanya dapat dilihat dari kinerja yang diperolehnya yaitu melalui laporan keuangan. Laporan keuangan koperasi 
merupakan alat yang sangat penting untuk memperoleh informasi sehubungan untuk mengetahui posisi keuangan dan hasil-hasil kegiatan koperasi, karena dengan adanya laporan keuangan, dapat mengetahui gambaran yang sebenarnya mengenai kondisi keuangan koperasi yang bersangkutan (Firdaus, 2014).

Ditinjau dari sisi keuangan, koperasi harus melakukan fungsi-fungsi keuangan yaitu pembiayaan dan investasi secara efektif dan efisien. Untuk mendeteksi hal tersebut, salah satu analisis yang dapat digunakan adalah analisis rasio keuangan. Analisis rasio keuangan terdiri dari rasio leverage, rasio likiuditas, rasio aktivitas dan rasio profitabilitas (Saraswati dkk, 2014).

Analisis ratio adalah suatu teknik untuk menganalisis laporan keuangan dari suatu koperasi atau badan usaha yang lain dengan menggunakan ukuran atau ratio tertentu, yang bertujuan untuk mengetahui kondisi keuangan suatu koperasi. Penilaian kinerja koperasi dari aspek financial dilakukan melalui analisis terhadap laporan keuangan dikemukakan oleh Mumek (2014). Rasio keuangan bertujuan untuk mendapat gambaran tentang baik buruknya keadaan keuangan suatu perusahaan pada saat dianalisis (Novyanti, 2013).

Koperasi memerlukan pengukuran kinerja keuangan koperasi untuk mengukur keberhasilan koperasi dalam meningkatkan kesejahteraan anggotanya. Pengukuran kinerja keuangan dapat dilakukan dengan menganalisis laporan keuangan (Murtizanah dan Kirwani, 2013). Modal kerja sangatlah penting karena merupakan salah satu bentuk sumber daya perusahaan yang terbatas dan dibutuhkan untuk membiayai aktivitas operasi perusahaan. Efektifitas modal kerja dapat dilihat melalui unsurunsur modal kerja yang meliputi aktiva lancar seperti kas, surat-surat berharga atau sekuritas, piutang dan persediaan. Modal kerja selama ini lebih banyak ditunjukan untuk perusahaan industri dan masih jarang ditunjukan untuk koperasi. Pengelolaan modal kerja dari suatu koperasi juga sangat diperlukan untuk menjamin kontinuitas atau menunjang kelancaran usaha. Manajemen modal kerja pada koperasi digunakan untuk membeli persediaan barang yang diperlukan anggota dan konsumen, membayar gaji pegawai, membayar hutang dagang, membayar bunga pinjaman serta untuk mendanai 
kegiatan lain yang menjadi kegiatan rutin koperasi (Susanto dkk, 2013).

Likuiditas adalah alat untuk mengukur kemampuan perusahaan dalam memenuhi kewajiban jangka pendeknya, dimana kewajiban pendek tersebut dibandingkan dengan aktiva (lancar) yang dimiliki perusahaan dikemukakan oleh Wijayanti (2010). Likuiditas yang tersedia harus cukup tidak boleh terlalu kecil sehingga mengganggu kebutuhan operasional sehari-hari tetapi juga tidak boleh terlalu besar karena akan menurunkan efisiensi dan berdampak pada rendahnya tingkat profitabilitas atau laba (Antonio dalam Wijayanti, 2010). Profitabilitas merupakan kemampuan perusahaan dalam menghasilkan laba. Rasio profitabilitas dalam penelitian ini diukur menggunakan Return On Assets (ROA) dan Return On Equity (ROE). Berdasarkan latar belakang tersebut diatas, maka penulis tertarik mengambil penelitian dengan judul "Pengaruh Likuiditas, Efektivitas Modal Kerja dan Leverage Terhadap Return On Assets (ROA) dan Return On Equity (ROE) pada Koperasi Pegawai Republik Indonesia (KPRI) di Kabupaten Lamongan”.

\section{TINJAUAN PUSTAKA}

\subsection{Profitabilitas}

Profitabilitas merupakan kemampuan suatu perusahaan dalam kegiatan operasionalnya untuk memperoleh laba atas penjualan, total aktiva maupun modal sendiri. Rasio profitabilitas adalah rasio yang digunakan untuk memberikan ukuran tingkat efektivitas manajemen suatu perusahaan dalam mendapatkan keuntungan (Kasmir, 2012: 196). Profitabilitas merupakan salah satu indikator keberhasilan suatu perusahaan untuk dapat menghasilkan laba. Ada tiga rasio yang dapat digunakan untuk mengukur tingkat profitabilitas suatu perusahaan yaitu: profit margin, return on asset (ROA), dan return on equity (ROE).

\subsection{Likuiditas}

Likuiditas merupakan kemampuan perusahaan mengubah aset yang dimiliki menjadi kas untuk memenuhi kewajiban finansial yang jatuh tempo (jangka pendek). Kemampuan perusahaan untuk memenuhi kewajiban finansial jangka pendek berasal dari alat-alat pembayaran (alat likuid) yang dimiliki perusahaan. 


\subsection{Modal Kerja}

Modal kerja merupakan salah satu hal yang penting bagi suatu perusahaan. Dengan modal kerja, suatu perusahaan dapat membiayai kegiatannya seharihari, misalnya: membeli persedian barang dagangan, membayar upah buruh, gaji karyawan dan sebagainya. Menurut Horne dan John (2009) terdapat dua konsep utama dari modal kerja yaitu modal kerja kotor dan modal kerja bersih.

\subsection{Leverage}

Leverage merupakan alat untuk mengukur seberapa jauh suatu perusahaan bergantung pada kreditor dalam membiayai aset perusahaan. Menurut Horne dan John (2009), leverage menunjukkan sejauh mana perusahaan dibiayai oleh utang.

\section{METODOLOGI PENELITIAN}

Penelitian ini termasuk dalam kategori penelitian deskriptif kuantitatif. Data yang digunakan dalam penelitian ini berupa laporan keuangan tahun 2010 sampai 2014. Metode pengambilan sampel dilakukan secara purposive sampling. Kriteria yang digunakan untuk memilih sampel dalam penelitian ini adalah : a. Koperasi Pegawai Republik Indonesia (KPRI) yang aktif menjadi anggota Pusat Koperasi Pegawai Republik Indonesia (PKPRI) dan tercatat di Dinas Koperasi Industri dan Perdagangan Kabupaten Lamongan.

b. Koperasi Pegawai Republik Indonesia (KPRI) menyerahkan laporan Rapat Anggota Tahunan (RAT) tahun 2010 sampai 2014 ke Pusat Koperasi Pegawai Republik Indonesia (PKP-RI) dan tercatat di Dinas Koperasi Industri dan Perdagangan Kabupaten Lamongan. c. Koperasi Pegawai Republik Indonesia (KPRI) yang mempunyai usaha pertokoan dan Asset lebih dari 3 Milyar.

Variabel yang digunakan dalam penelitian ini adalah sebagai berikut:

1. Likuiditas $\left(\mathrm{X}_{1}\right)$

Digunakan untuk mengukur kemampuan perusahaan untuk memenuhi kewajiban keuangan jangka pendek. Yang dapat dirumuskan sebagai berikut:

Likuiditas $=\frac{\text { Aktiva Lancar }}{\text { Pasiva Lancar }} \times 100 \%$ 
Tabel 1. Klasifikasi Likuiditas

\begin{tabular}{|c|c|c|}
\hline $\begin{array}{c}\text { Tingkat } \\
\text { Likuiditas }\end{array}$ & Nilai & Kriteria \\
\hline $200 \%$ s/d $250 \%$ & 100 & Efektif \\
\hline $\begin{array}{c}175 \% \text { s/d }<200 \% \\
\text { atau } \\
>250 \% \text { s/d } 275 \%\end{array}$ & 75 & $\begin{array}{c}\text { Cukup } \\
\text { Efektif }\end{array}$ \\
\hline $\begin{array}{c}150 \% \text { s/d }<175 \% \\
\text { atau } \\
>275 \% \text { s/d } 300 \%\end{array}$ & 50 & $\begin{array}{c}\text { Tidak } \\
\text { Efektif }\end{array}$ \\
\hline
\end{tabular}

\section{Efektivitas Modal Kerja/ Working}

$$
\text { capital turnover }\left(\mathrm{X}_{2}\right)
$$

Merupakan suatu ukuran bagaimana modal kerja perusahaan dapat digunakan sebaik-baiknya untuk mencapai tujuan perusahaan. Yang dirumuskan sebagai berikut :

Working capital turnover $=$

$\frac{\text { Modal Kerja }}{\text { Total Penjualan }}$

Tabel 2. Klasifikasi Efektivitas Modal Kerja

\begin{tabular}{|c|c|c|}
\hline $\begin{array}{c}\text { Tingkat } \\
\text { Perputaran } \\
\text { Modal Kerja }\end{array}$ & Nilai & Kriteria \\
\hline$\geq 5,3$ & 100 & Sangat Efektif \\
$2,5 \mathrm{~s} / \mathrm{d}<3,5$ & 75 & Efektif \\
$1,5 \mathrm{~s} / \mathrm{d}<2,5$ & 50 & Cukup Efektif \\
$1 \mathrm{~s} / \mathrm{d}<1,5$ & 25 & Kurang Efektif \\
$<1$ & 0 & Tidak Efektif \\
\hline
\end{tabular}

3. Leverage/ Total Debt to Equity Ratio $\left(\mathrm{X}_{3}\right)$

Rasio yang mengukur sejauh mana kemampuan perusahaan memenuhi kewajiban jangka panjangnya. Yang dapat dirumuskan sebagai berikut:
DER $=\frac{\text { Total Kewajiban }}{\text { Modal Sendiri }} \times 100 \%$

Tabel 3. Klasifikasi Total Debt to Equity Ratio

\begin{tabular}{|c|c|c|}
\hline $\begin{array}{c}\text { Tingkat Total Debt } \\
\text { to Equity Ratio }\end{array}$ & Nilai & Kriteria \\
\hline$\leq 70 \%$ & 100 & Sangat Efektif \\
$>70 \%$ s/d $100 \%$ & 75 & Efektif \\
$>100 \%$ s/d $150 \%$ & 50 & Cukup Efektif \\
$>150 \%$ s/d $200 \%$ & 25 & Kurang Efektif \\
$\geq 200$ & 0 & Tidak Efektif \\
\hline
\end{tabular}

\section{Return On Assets $\left(\mathrm{Y}_{1}\right)$}

Rasio ini digunakan untuk mengukur kemampuan manajemen perusahaan dalam memperoleh keuntungan (laba) secara keseluruhan. Yang dirumuskan sebagai berikut :

$$
\mathrm{ROA}=\frac{\text { Sisa Hasil Usaha }}{\text { Total Aktiva }} \times 100 \%
$$

Tabel 4. Klasifikasi Return on Assets

\begin{tabular}{|c|c|c|}
\hline Tingkat ROA & Nilai & Kriteria \\
\hline$\geq 10 \%$ & 100 & Sangat Efektif \\
$7 \% \mathrm{~s} / \mathrm{d}<10 \%$ & 75 & Efektif \\
$3 \% \mathrm{~s} / \mathrm{d}<7 \%$ & 50 & Cukup Efektif \\
$1 \% \mathrm{~s} / \mathrm{d}<3 \%$ & 25 & Kurang Efektif \\
$\leq 1 \%$ & 0 & Tidak Efektif \\
\hline
\end{tabular}

\section{Return On Equity $\left(\mathrm{Y}_{2}\right)$}

Rasio ini menunjukan kemampuan modal pemilik yang ditanamkan oleh pemilik atau investor untuk menghasilkan laba bersih yang menjadi bagian dari pemilik. Yang dapat dirumuskan sebagai berikut : 


$$
\mathrm{ROE}=\frac{\text { Sisa Hasil Usaha }}{\text { Modal Sendiri }} \times 100 \%
$$

Tabel 5. Klasifikasi Return on Equity

\begin{tabular}{|c|c|c|}
\hline Tingkat & Nilai & Kriteria \\
\hline$\geq 21 \%$ & 100 & Sangat Efektif \\
$15 \% \mathrm{~s} / \mathrm{d}<21 \%$ & 75 & Efektif \\
$9 \% \mathrm{~s} / \mathrm{d}<15 \%$ & 50 & Cukup Efektif \\
$3 \% \mathrm{~s} / \mathrm{d}<9 \%$ & 25 & Kurang Efektif \\
$\leq 3 \%$ & 0 & Tidak Efektif \\
\hline
\end{tabular}

\section{HASIL PENELITIAN DAN PEMBAHASAN}

4.1 Analisis Regresi Likuiditas, Efektivitas Modal Kerja dan Leverage terhadap ROA

Berdasarkan Tabel 6 diperoleh persamaan regresi linier berganda sebagai berikut :

$$
\begin{aligned}
\text { ROA }= & 182,525+0,005 X_{1}+0,001 X_{2} \\
& -0,006 X_{3}
\end{aligned}
$$

Tabel 6. Model Regresi Linier untuk ROA

\begin{tabular}{|l|r|r|r|r|r|}
\hline \multirow{2}{*}{ Model } & \multicolumn{2}{|c|}{$\begin{array}{c}\text { Unstandardized } \\
\text { Coefficients }\end{array}$} & $\begin{array}{c}\text { Standardized } \\
\text { Coefficients }\end{array}$ & \multirow{2}{*}{ t } & \multirow{2}{*}{ Sig. } \\
\cline { 2 - 4 } & \multicolumn{1}{|c|}{ B } & \multicolumn{1}{c|}{ Std. Error } & \multicolumn{1}{c|}{ Beta } & & \\
\hline (Constant) & 182.525 & 18.559 & & 9.835 & 0.000 \\
\hline Likuiditas & 0.005 & 0.000 & -0.019 & -0.165 & 0.870 \\
\hline Efektivitas Modal Kerja & 0.001 & 0.001 & 0.140 & 1.214 & 0.231 \\
\hline Leverage & -0.006 & 0.001 & -0.637 & -5.646 & 0.000 \\
\hline
\end{tabular}

Sumber : Hasil olah data SPSS

Hasil perhitungan regresi berganda menunjukan Konstanta $(\alpha)$ diperoleh sebesar 182,525. Hasil tersebut menyatakan bahwa jika variabel independen (Likuiditas, Efektivitas Modal Kerja dan Leverage) bernilai nol, maka Return On Assets bernilai sebesar 182,525. Koefisien Likuiditas $\left(\mathrm{X}_{1}\right)$ diperoleh sebesar 0,005. Hasil ini menunjukan bahwa jika ada kenaikan satu satuan Likuiditas akan diikuti dengan kenaikan Return On Assets sebesar 0,005 dan variabel independen lainnya dianggap konstan. Koefisien
Efektivitas Modal Kerja $\left(\mathrm{X}_{2}\right)$ diperoleh sebesar 0,001. Hasil ini menunjukan bahwa jika ada kenaikan satu satuan Efektivitas Modal Kerja akan diikuti dengan kenaikan Return On Assets sebesar 0,001 dan variabel independen lainnya dianggap konstan. Koefisien Leverage $\left(X_{3}\right)$ diperoleh sebesar $-0,006$. Hasil ini menunjukan bahwa jika ada kenaikan satu satuan Leverage akan diikuti dengan penurunan Return On Assets sebesar 0,006 dan variabel independen lainnya dianggap konstan. 
Berdasarkan Tabel 6 diatas dapat diketahui bahwa Likuiditas memiliki $\mathrm{t}_{\text {hitung }}$ bertanda negatif sebesar $-0,165$ dengan coefficients sig sebesar 0,870 berarti coefficients sig $(0,870)>$ tingkat signifikansi $(0,05)$ sehingga Likuiditas tidak mempunyai pengaruh yang signifikan terhadap Return On Assets (ROA). Efektivitas Modal Kerja memiliki $t_{\text {hitung }}$ bertanda positif sebesar 1,214 dengan coefficients sig sebesar 0,231 berarti coefficients sig $(0,231)>$ tingkat signifikansi $(0,05)$ sehingga Efektivitas Modal Kerja tidak mempunyai pengaruh yang signifikan terhadap Return On Assets (ROA). Leverage memiliki $t_{\text {hitung }}$ bertanda negatif sebesar -5,645 dengan coefficients sig sebesar 0,000 berarti coefficients sig $(0,000)$ < tingkat signifikansi $(0,05)$ sehingga Leverage mempunyai pengaruh yang signifikan terhadap Return On Assets (ROA). Hasil ini mengidentifikasikan bahwa besarnya Leverage koperasi berpengaruh signifikan terhadap Return On Assets (ROA).

Berdasarkan Tabel 7, menunjukan bahwa nilai dari $F_{\text {tabel }}$ sebesar 2,200 dan diketahui nilai perolehan $\mathrm{F}_{\text {hitung }}$ 10,627. Karena $F_{\text {hitung }} 10,627>F_{\text {tabel }} 2,200$ sehingga variabel Likuiditas, Efektivitas Modal Kerja dan Leverage secara bersama-sama memiliki pengaruh signifikan terhadap Return On Assets (ROA).

Tabel 7. Hasil Uji Anova Model Regresi Linier untuk ROA

\begin{tabular}{|l|r|r|r|r|r|}
\hline \multicolumn{1}{|c|}{ Model } & Sum of Squares & \multicolumn{1}{c|}{ df } & $\begin{array}{c}\text { Mean } \\
\text { Square }\end{array}$ & F & \multicolumn{1}{c|}{ Sig. } \\
\hline Regression & 88903.186 & 3 & 29634.395 & 10.627 & 0.000 \\
\hline Residual & 142220.160 & 51 & 2788.631 & & \\
\hline Total & 231123.345 & 54 & & & \\
\hline
\end{tabular}

4.2 Analisis Regresi Likuiditas, Efektivitas Modal Kerja dan Leverage terhadap ROE

Berikut adalah hasil analisis regresi berganda antara likuiditas, efektifitas modal kerja dan leverage terhadap ROE.
Berdasarkan Tabel 8 diperoleh persamaan regresi linier berganda sebagai berikut :

$$
\begin{aligned}
\mathrm{ROE}= & 232,984+0,001 \mathrm{X}_{1}+0,002 \mathrm{X}_{2} \\
& -0,005 \mathrm{X}_{3}
\end{aligned}
$$


Tabel 8. Model Regresi Linier untuk ROE

\begin{tabular}{|l|r|r|r|r|r|}
\hline \multirow{2}{*}{ Model } & \multicolumn{2}{|c|}{$\begin{array}{c}\text { Unstandardized } \\
\text { Coefficients }\end{array}$} & $\begin{array}{c}\text { Standardized } \\
\text { Coefficients }\end{array}$ & \multirow{2}{*}{ t } & \multirow{2}{*}{ Sig. } \\
\cline { 2 - 3 } & \multicolumn{1}{|c|}{ B } & Std. Error & \multicolumn{1}{c|}{ Beta } & & \\
\hline (Constant) & 232.984 & 27.592 & & 8.444 & 0.000 \\
\hline Likuiditas & 0.001 & 0.000 & 0.195 & 1.494 & 0.141 \\
\hline Efektivitas Modal Kerja & 0.002 & 0.001 & 0.206 & 1.538 & 0.130 \\
\hline Leverage & -0.005 & 0.002 & -0.367 & -2.805 & 0.007 \\
\hline
\end{tabular}

Hasil perhitungan regresi berganda menunjukan Konstanta $(\alpha)$ diperoleh sebesar 232,984. Hasil tersebut menyatakan bahwa jika variabel independen (Likuiditas, Efektivitas Modal Kerja dan Leverage) bernilai nol, maka Return On Equity (ROE) bernilai sebesar 232,984. Koefisien Likuiditas $\left(\mathrm{X}_{1}\right)$ diperoleh sebesar 0,001. Hasil ini menunjukan bahwa jika ada kenaikan satu satuan Likuiditas akan diikuti dengan kenaikan ROE sebesar 0,001 dan variabel independen lainnya dianggap konstan. Koefisien Efektivitas Modal Kerja $\left(\mathrm{X}_{2}\right)$ diperoleh sebesar 0,002 . Hasil ini menunjukan bahwa jika ada kenaikan satu satuan Efektivitas Modal Kerja akan diikuti dengan kenaikan ROE sebesar 0,002 dan variabel independen lainnya dianggap konstan. Koefisien Leverage $\left(\mathrm{X}_{3}\right)$ diperoleh sebesar $-0,005$. Hasil ini menunjukan bahwa jika ada kenaikan satu satuan Leverage akan diikuti dengan penurunan ROE sebesar 0,005 dan variabel independen lainnya dianggap konstan.
Berdasarkan keterangan diatas dapat diketahui bahwa Leverage memiliki $\mathrm{t}_{\text {hitung }}$ bertanda positif sebesar 1,494 dengan coefficients sig sebesar 0,141 berarti coefficients sig $(0,141)>$ tingkat signifikansi $(0,05)$ sehingga Likuiditas tidak mempunyai pengaruh yang signifikan terhadap Return On Equity (ROE). Efektivitas Modal Kerja memiliki $t_{\text {hitung }}$ bertanda positif sebesar 1,538 dengan coefficients sig sebesar 0,130 berarti coefficients sig $(0,130)>$ tingkat signifikansi $(0,05)$ sehingga Efektivitas Modal Kerja tidak mempunyai pengaruh yang signifikan terhadap Return On Equity (ROE). Leverage memiliki $t_{\text {hitung }}$ bertanda negatif sebesar -2,805 dengan coefficients sig sebesar 0,007 Hal tersebut menunjukan bahwa coefficients sig $(0,007)<$ tingkat signifikansi $(0,05)$ sehingga Leverage mempunyai pengaruh yang signifikan terhadap Return On Equity (ROE).

Berdasarkan Tabel 9 menunjukkan bahwa nilai dari $\mathrm{F}_{\text {tabel }}$ sebesar 2,200 dan diketahui nilai perolehan $\mathrm{F}_{\text {hitung }}$ 1,637. 
Karena $F_{\text {hitung }} 1,637<\mathrm{F}_{\text {tabel }} 2,200$ signifikan terhadap Return On Equity sehingga variabel Likuiditas, Efektivitas (ROE).

Modal Kerja dan Leverage secara bersama-sama tidak memiliki pengaruh

Tabel 9. Hasil Uji Anova Model Regresi Linier untuk ROE

\begin{tabular}{|l|r|r|r|r|c|}
\hline \multicolumn{1}{|c|}{ Model } & Sum of Squares & \multicolumn{1}{c|}{ df } & Mean Square & \multicolumn{1}{c|}{ F } & \multicolumn{1}{c|}{ Sig. } \\
\hline Regression & 33346.364 & 3 & 11115.455 & 1,637 & 0.192 \\
\hline Residual & 346379.381 & 51 & 6791.753 & & \\
\hline Total & 379725.745 & 54 & & & \\
\hline
\end{tabular}

\section{PENUTUP}

\subsection{Simpulan}

Variabel Likuiditas berpengaruh secara negatif dan tidak signifikan terhadap Return On Assets (ROA) pada Koperasi Pegawai Republik Indonesia di Kabupaten Lamongan periode 20102014 dan Variabel Likuiditas berpengaruh secara positif dan tidak signifikan terhadap Return On Equity (ROE) pada Koperasi Pegawai Republik Indonesia di Kabupaten Lamongan periode 2010-2014. Variabel Efektivitas Modal Kerja berpengaruh secara positif tetapi tidak signifikan terhadap Return On Assets (ROA) pada Koperasi Pegawai Republik Indonesia di Kabupaten Lamongan periode 20102014 dan Variabel Efektivitas Modal Kerja berpengaruh secara positif tetapi tidak signifikan terhadap Return On Equity (ROE) pada Koperasi Pegawai Republik Indonesia periode di
Kabupaten Lamongan 2010-2014. Variabel Leverage berpengaruh secara negatif dan signifikan terhadap Return On Assets (ROA) pada Koperasi Pegawai Republik Indonesia di Kabupaten Lamongan periode 20102014 dan Variabel Leverage berpengaruh secara negatif dan signifikan terhadap Return On Equity (ROE) pada Koperasi Pegawai Republik Indonesia di Kabupaten Lamongan periode 2010-2014. Variabel Likuiditas, Efektivitas Modal Kerja dan Leverage secara bersama berpengaruh positif dan signifikan terhadap Return On Assets (ROA) pada Koperasi Pegawai Republik Indinesia di Kabupaten Lamongan periode 2010-2014 dan Variabel Likuiditas, Efektivitas Modal Kerja dan Leverage secara bersama tidak berpengaruh positif dan signifikan terhadap Return On Equity (ROE) pada Koperasi Pegawai Republik Indinesia di 
Kabupaten Lamongan periode 20102014.

\subsection{Saran}

Dalam penelitian ini hanya ada 3 rasio keuangan saja yang digunakan untuk memprediksi Tingkat Profitabilitas koperasi yaitu Likuiditas, Efektivitas Modal Kerja dan Leverage. Untuk peneliti selanjutnya diharapkan untuk menambah factor-faktor lain yang dapat mempengaruhi Profitabilitas koperasi. Sebaiknya periode pengamatan untuk penelitian selanjutnya menggunakan periode yang lebih panjang dari pengamatan penelitian ini, hal ini bertujuan untuk memperkuat hasil penelitian. Disamping memenuhi kebutuhan anggotanya, koperasi perlu juga menjual barang untuk umum secara tunai. Selalu disosialisasikan kepada anggota yang punya kewajiban memenuhi kewajiban tepat waktu agar koperasi tetap eksis terus.

\section{DAFTAR PUSTAKA}

Firdaus, Filjannatul. 2014. Analisis $\begin{array}{lrr}\text { Rasio } & \text { Likuiditas, } & \text { Rasio } \\ \text { Solvabilitas } & \text { dan } & \text { Rasio } \\ \text { Profitabilitas } & \text { Terhadap } & \text { Kinerja } \\ \text { Koperasi } & \text { As-Sakinah di } & \text { Sidoarjo }\end{array}$
Tahun 2009-2012. Online: ejournal.unesa.ac.id.

Horne, J. C. V. dan John M.M. 2009. Prinsip-Prinsip Manajemen Keuangan. Jakarta: Salemba Empat.

Kasmir. 2012. Analisis Laporan Keuangan. Jakarta: PT. Raja Grafindo Persada.

Mumek, Monica Priscila. 2014. Analisis Likuiditas Koperasi Simpan Pinjam Karangtawaya Desa Sendangan Kecamatan Remboken Kabupaten Minahasa. Online: ejournal.unsrat.ac.id.

Murtizanah, Diah Ika dan Kirwani. 2013. Analisis Pengaruh Rasio Likuiditas dan Rasio Aktivitas Terhadap Profitabilitas KPRI Makmur Krian. Online: ejournal.unesa.ac.id. Vol. 1 No. 3. 